\title{
Uveitis in association with multiple sclerosis
}

\author{
RIGHARD PORTER \\ University Department of Ophthalmology, Royal Victoria Infirmary, Newcastle upon Tyne
}

Rucker (I944) was first to describe sheathing of retinal veins in patients with multiple 흥. sclerosis. This was supported by later observers (Treusch and Rucker, 1944; Haar, I 953;\% Scott, I96r), but the incidence was found to vary from ro to 23 per cent. It was initially thought that this periphlebitis was not associated with other ocular conditions, and might $\infty$ indicate a possible pathological basis for multiple sclerosis, with areas of periphlebitis옥 scattered throughout the central nervous system. Later reports, however, demonstrated $\vec{c}$ an association between this retinal vein sheathing and a posterior uveitis in similar patients (Archambeau, Hollenhorst, and Rucker, I965), and more recently an association has been demonstrated between multiple sclerosis and the clinical entity of peripheral uveitis (pars planitis) (Breger and Leopold, I966; Giles, 1970), which may include sheathing of the retinal veins (Brockhurst, Schepens, and Okamura, 1960). Other workers have failed to confirm these findings and feel that retinal sheathing represents a retinal light reflex (Field and Foster, 1962). More recently other observers have failed to find any

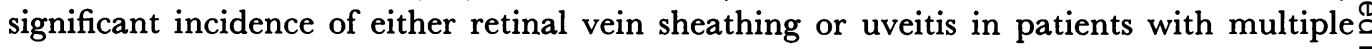
sclerosis (Lössner, Müller, and Bachman, I968).

In view of these conflicting reports, and the persistent similarities between the latest theories concerning the aetiologies of both uveitis and multiple sclerosis, it was considered worthwhile to carry out a new ocular survey of patients with multiple sclerosis.

\section{Method}

A total of sixty patients was examined, 25 male and 35 female, varying in age from 18 to 65 years $\frac{\delta}{3}$ with an average age of 40 years. They had all had the diagnosis of multiple sclerosis confirmed by a neurologist.

The anterior segment and anterior vitreous were examined by slit-lamp microscopy and the pos- $\frac{D}{0}$ terior segment of all eyes was examined, after pupillary dilatation, by direct and indirect ophthalmoscopy.

\section{Results}

In the sixty patients examined, nine (I 5 per cent.) had signs of a uveitis, and seven of thesec ( I I 7 per cent.) had sheathing of the retinal veins (Table). Only four patients complained of an inflamed eye and in only one (Case 40) was it the presenting symptom. Fifteen (25 per cent.) of the patients had had a retrobulbar neuritis as the presenting symptom and these included four of the patients with uveitis. Two of the patients had signs worthy of note in the posterior segment, but were not included in the 15 per cent. One patient $\stackrel{\mathbb{Q}}{\Omega}$ had a fibrous plaque overlying a retinal vein similar to that described by Rucker in his original report (Rucker, 1944) but without other ocular involvement, and the other 8 
Table Ocular findings in nine patients found to have signs of uveitis

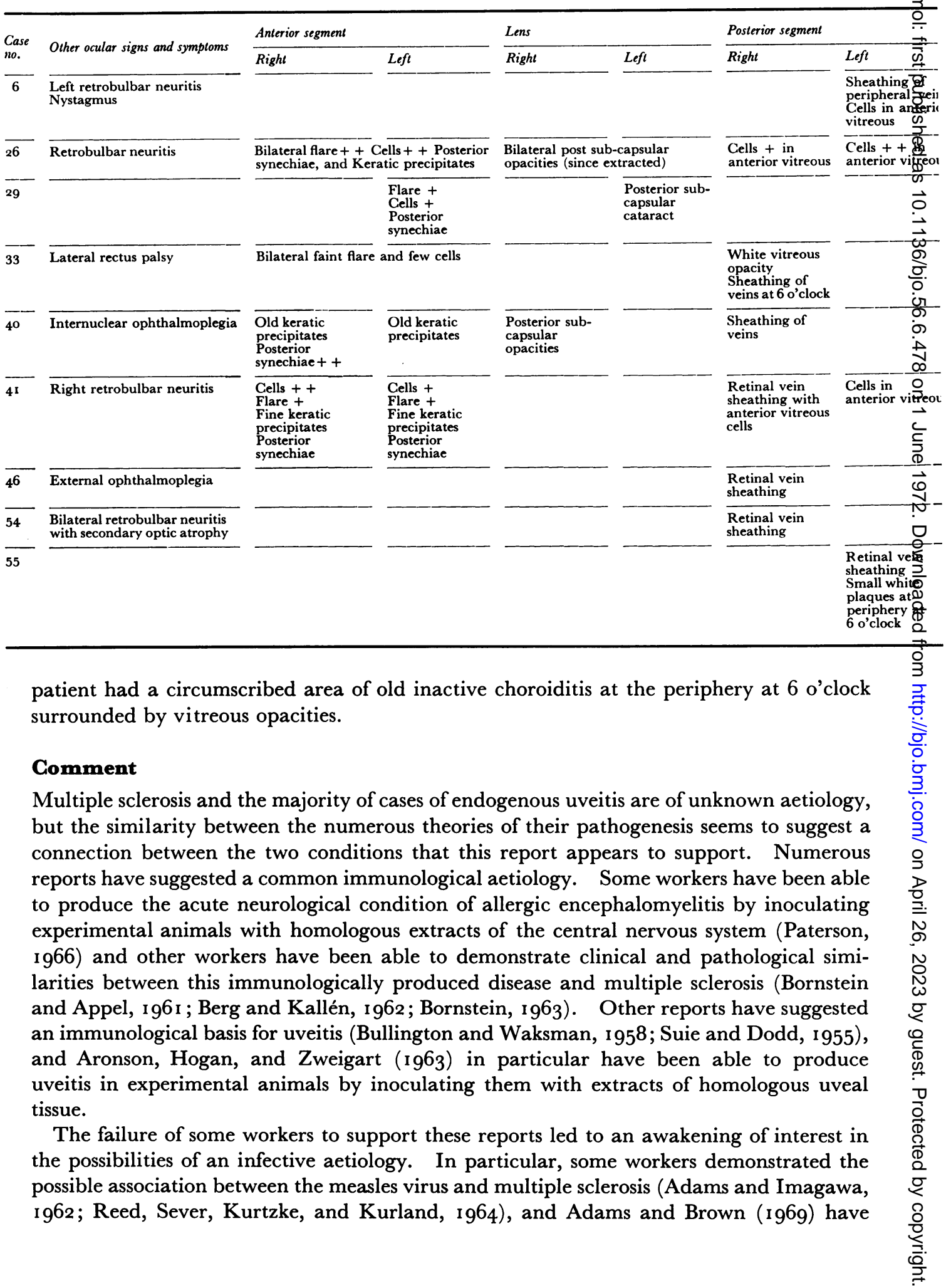


suggested that multiple sclerosis is a "slow" infection of the central nervous system with the $\frac{\sqrt{\frac{0}{3}}}{3}$ measles virus. More recently evidence has accumulated to suggest that two chronico믐 neurological diseases in man, Creutzfeldt-Jacob disease and Kuru, are due to infection of the central nervous system with slow viruses (Gibbs, Gajdusek, Asher, Alpers, Beck $\stackrel{?}{+}$ Daniel, and Matthews, 1968; Gajdusek, Gibbs, and Alpers, 1966), and other workers등 have presented evidence of a connection between slow viruses and the diseases of subacute panencephalitis (Connolly, Allen, Hurwitz, and Millar, 1967; Freeman, Magoffin,,$\stackrel{\varnothing}{\circ}$ Lennette, Herndon, 1967) and multiple sclerosis (Field, Miller, and Russell, 1962; ; Campbell, Norman, and Sandry, 1963).

Similarly attempts have been made to demonstrate the presence of viruses in several types of uveitis, and in cases of the uveitis associated with Behçet's disease (Sezer, $\vec{\omega}$ r 953; Mortada and Imam, r964) and with the uveo-meningeal syndromes of Vogt-․ㅡㅇ. Koyanagi and Harada (Yoshida, 1960; Morris and Schlaegel, 1969) this seems to have beenig successful, although several workers have failed to confirm it. These syndromes are ofo particular interest in that the uveitis is often associated with an inflammatory involvement of the central nervous system.

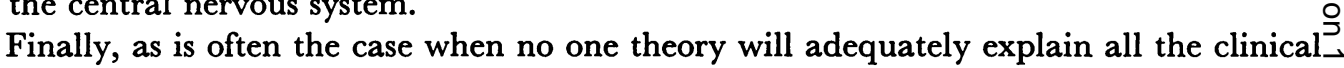
and pathological features of a disease, attempts have been made to combine some features $\subseteq$ of the available theories. Thus, with uveitis (Hallett, Wolkowicz, Leopold, Canamucio, and Wijewski, I962) and multiple sclerosis, numerous workers have suggested that an $\vec{\varphi}$ immune response and a virus infection are necessary to produce the full clinical picture, N either by an acute antibody antigen reaction awakening a latent virus infection or by a virus infection producing antigenic substances which promote an immunological response.

\section{Summary}

A survey of sixty patients with multiple sclerosis showed nine ( 15 per cent.) to have an⿳亠丷厂 associated uveitis. The possible association between the two diseases is discussed.

I wish to thank Mr. A. L. Crombie for his help and Dr. E. H. Jarvis, Dr. H. G. Miller, and Dr. D. Shaw ford permission to examine patients admitted under their care.

\section{References}

ADAms, J. M., and Brown, w. J. (1969) "Contributions to the Pathogenesis of Demyelinating음

Disease". Cited by Paterson (1969)

- and Imagawa, D. T. (1962) Proc. Soc. exp. Biol. (N.Y.Y.), I11, 562

ARGhambeaU, P. L., hollenhorst, R. W., and RUCKez, c. W. (1965) Proc. Mayo Clin., 40, 544

ARonson, s., hogan, M., and zWeigart, P. (1963) Arch. Ophthal. (Chicago), 69, 105, 203

BERG, O., and KALLÉN, B. (1962) Acta path. microbiol. scand., 54, 425

BORNSTEIN, M. B. (1963) Nat. Cancer Inst. Monograph, no. I I, p. 197

- and APPEL, S. H. (196r) J. Neuropath. exp. Neurol., 20, 14I

BREGER, B. C., and LEOPOLD, I. H. (1966) Amer. F. Ophthal., 62, 540

BROCKHURST, R. J., SCHEPENS, C. L., and OKAMURA, I. D. (1960) Ibid., 49, 1257

bullington, s. J., and waksman, B. H. (1958) A.M.A. Arch. Ophthal., 58, 435

CAMPBell, A. M. G., NORMaN, R. M., and SANDRY, R. J. (1963) F. Neurol. Neurosurg. Psychiat., 26, 439

CONNOLly, J. H., ALlen, I. V., HURWTTZ, L. J., and millaR, J. H. D. (1967) Lancet, I, 542

Field, E. J., and foster, J. B. (1962) $\quad$ F. Neurol. Neurosurg. Psychiat., 25, 269

- Miller, H., and Russell, D. s. (1962) J. clin. Path., 15, 278

FREEMAN, J. M., MAGOFFIN, R. L., LENNETTE, E. H., and HERNDON, R. M. (1967) Lancet, 2, 129 
GAJDUSEK, D., GIBBS, C. T., and ALPERS, M. (1966) Nature (Lond.), 209, 794

GibBS, C. J., GAJDUSEK, D. C., ASher, D. M., ALPERS, M., BECK, E., DANIEL, P. M., and MATTHEWS, W. B.

(1968) Science, r6r, 388

GILES, C. L. (1970) Amer. F. Ophthal., 70, 17

HAAR, M. (1953) Acta psychiat. neurol. scand., 28, I 75

hallett, J. W., Wolkowicz, M. I., Leopold, I., canamucio, c., and wijewski, E. (1962) Arch.

Ophthal. (Chicago), 68, 168

Lössner, J., müller, J., and bachman, h. (1968) Psychiat. Neurol. med. Psychol., 20, 348

MORRIS, W., and SCHLAegel, T. F. (1964) Amer. F. Ophthal., 58, 940

MORTADA, A., and IMAN, I. Z. E. (1964) Brit. J. Ophthal., 48, 250

PATERSON, P. Y. (1966) Advanc. Immunol., 5, 131

(1969) Ann. Rev. Med., 20, 91

REED, D., SEVER, J., KURTZKe, J., and KURLAND, L. (1964) Arch. Neurol., 10, 402

RUCKer, c. W. (1944) Proc. Mayo Clin., 19, 176

SEZER, N. (1953) Amer. F. Ophthal., 41, 4 I

scott, G. I. (1961) Proc. roy. Soc. Med., 54, 38

suiE, т., and DODD, м. с. (1955) Amer. F. Ophthal., 39, 377

TreUsch, J. v., and RUCKer, c. w. (1944) Proc. Mayo Clin., 19, 253

yoshidA, E. (1960) Acta Soc. ophthal. jap., 64, 231 